\title{
Fourth branchial fistula: a rare cause of persistent neck discharge in an adult
}

\author{
Bharat Hosur, ${ }^{1}$ Vivek Gupta, ${ }^{2}$ Chirag Kamal Ahuja ${ }^{1}$
}

${ }^{1}$ Department of Radiodiagnosis and Imaging, Postgraduate Institute of Medical Education and Research (PGIMER),

Chandigarh, India

${ }^{2}$ Department of Radiodiagnosis and Imaging (Neuroradiology Section), Postgraduate Institute of Medical Education and Research, Chandigarh, India

\section{Correspondence to}

Dr Vivek Gupta,

drvivekgupta.pgi@gmail.com

Accepted 4 November 2018

Check for updates

(C) BMJ Publishing Group Limited 2018. No commercial re-use. See rights and permissions. Published by BMJ.

\begin{tabular}{l}
\hline To cite: Hosur B, Gupta V, \\
Ahuja CK. BMJ Case \\
Rep 2018;11:e227980. \\
doi:10.1136/bcr-2018- \\
227980 \\
\hline
\end{tabular}

\section{DESCRIPTION}

A 31-year-old woman with no comorbidities presented with persistent pus discharge from the left side of her neck for about a month. She did not have fever or neck mass. There was no history of invasive medical procedure or trauma to the neck. Episodes of similar pus discharge were also present in her childhood. Ultrasonogram of the neck ruled out significant cervical lymphadenopathy and focal fluid collection. Neck radiographs were unremarkable.

Contrast-enhanced CT scan showed a column of air loculi (figure $1 \mathrm{~A}-\mathrm{C}$ ) along the left thyroid lobe reaching up to the indurated skin. A fistula was suspected, and hence CT sinogram was done with percutaneous iodinated contrast injection. A contrast-filled track (figure 1D-F) was seen with the cutaneous end at the level of the inferior margin of the cricoid. Internally, it ended in the pyriform sinus with its course along the posterosuperior aspect of the left thyroid lobe, anterior to the left sternocleidomastoid and medial to the left carotid sheath (figure 2). A thin pool of contrast was appreciated in the hypopharynx.

Persistent fourth branchial remnant, typically sited between the thyroid and the pyriform sinus apex, is the rarest among the branchial anomalies. Due to asymmetric involution of the arches, it is more common on the left side, usually as a blind sinus in a child. A true fistula, as seen in our patient, is extremely rare. ${ }^{1}$ Previously, a barium swallow was

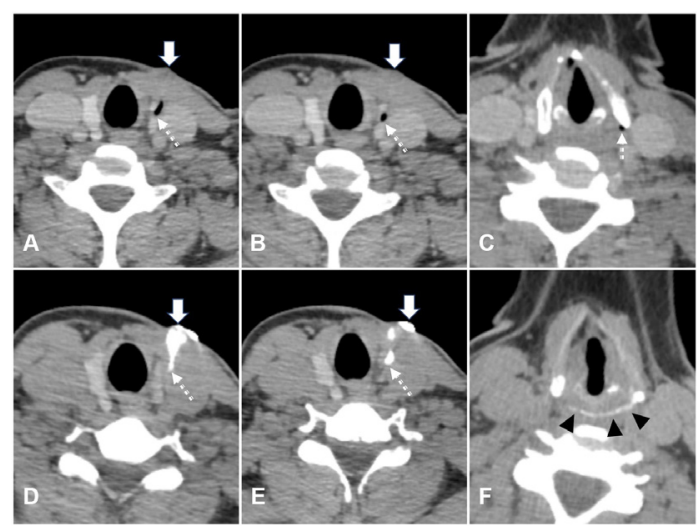

Figure 1 Axial contrast-enhanced CT neck images (A-C) from the superior aspect of the thyroid to the level of pyriform sinus showing hypodense air loculi (dotted arrow) tracking from the indurated skin (solid arrow). CT sinogram images at same levels (D-F) showing contrast-filled fistula (dotted arrow) tracking from the cutaneous opening (solid arrow) to the left pyriform sinus with a thin pool of contrast (arrowheads).

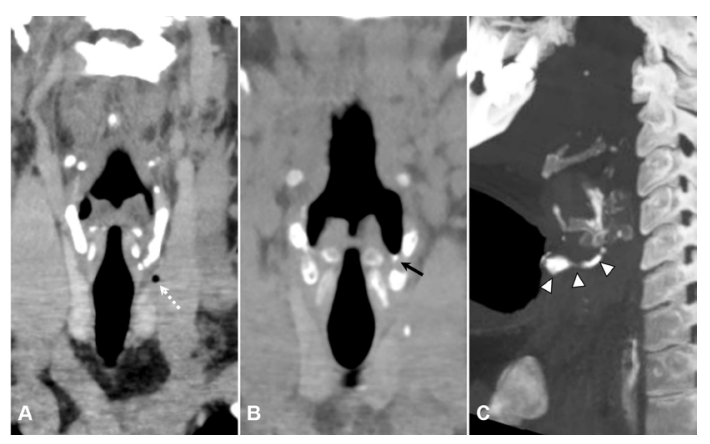

Figure 2 (A) Coronal contrast-enhanced CT of the neck showing a hypodense air locule (dotted arrow) in relation to the left thyroid lobe. (B) Coronal CT sinogram image showing a thin layering of contrast in the left pyriform sinus (black arrow). (C) Oblique sagittal thick maximum intensity projection showing the course of the left fourth branchial fistula in toto (arrowheads).

considered essential for diagnosis. ${ }^{2}$ Newer imaging modalities provide greater diagnostic accuracy and preoperative planning. Although ultrasound with 'trumpet-manoeuvre' and T2-weighted MRI are

\section{Patient's perspective}

The recurrent neck discharge was a nagging problem for me. Off-late, I was becoming increasingly anxious, as no exact diagnosis was offered despite multiple referrals. After this CT scan with dye injection in my neck, I am told that it is just a congenital tract with lingering infection and not some kind of a cancer. I feel so relieved, finally a diagnosis is revealed. I hope it will lead to correct treatment and freedom from this long-standing problem.

\section{Learning points}

Fourth branchial fistulas can be a rare cause of recurrent/non-healing, persistent, discharging cutaneous sinus or a neck abscess with or without involvement of the thyroid, even in adults.

- Abnormal air loculi or collections in relation to thyroid gland on CT scan of the neck are important imaging pointers.

- Meticulous CT sinogram using iodinated contrast media is the imaging modality of choice for diagnosis as well as surgical planning. 
alternatives, CT sinography remains the imaging modality of choice.

Contributors $\mathrm{BH}$ and $\mathrm{VG}$ contributed to the conception, design, acquisition and interpretation of the imaging. BH drafted and revised the article, and CKA and VG reviewed it critically for important intellectual content. VG gave the final approval for the version to be published.

Funding The authors have not declared a specific grant for this research from any funding agency in the public, commercial or not-for-profit sectors.

Competing interests None declared.
Patient consent Obtained.

Provenance and peer review Not commissioned; externally peer reviewed.

\section{REFERENCES}

1 Thomas B, Shroff M, Forte V, et al. Revisiting imaging features and the embryologic basis of third and fourth branchial anomalies. AJNR Am J Neuroradiol 2010;31:755-60.

2 Godin MS, Kearns DB, Pransky SM, et al. Fourth branchial pouch sinus: principles of diagnosis and management. Laryngoscope 1990;100:174-8.

Copyright 2018 BMJ Publishing Group. All rights reserved. For permission to reuse any of this content visit

https://www.bmj.com/company/products-services/rights-and-licensing/permissions/

BMJ Case Report Fellows may re-use this article for personal use and teaching without any further permission.

Become a Fellow of BMJ Case Reports today and you can:

- Submit as many cases as you like

- Enjoy fast sympathetic peer review and rapid publication of accepted articles

- Access all the published articles

Re-use any of the published material for personal use and teaching without further permission

For information on Institutional Fellowships contact consortiasales@bmjgroup.com

Visit casereports.bmj.com for more articles like this and to become a Fellow 